\title{
Success Strategies for Small Financial Planning Firms
}

\author{
Joanne H. Snider \\ Walden University \\ Kevin J. Davies \\ Walden University
}

Small Business Administration statistics indicate that $20 \%$ of small businesses fail within the first 2 years and $50 \%$ fail within 5 years. The purpose of this case study was to explore the success factors and strategies of 12 small business owners of independent financial planning firms who achieved profitability beyond 5 years. The conceptual framework was entrepreneurship theory and Porter's five forces model of competitive strategy. The data gathering method included semistructured interviews and analysis of business artifacts such as websites and newsletters. Initial coding of the responses preceded an analysis of recurring patterns and themes. The major themes identified were: technical training is necessary but not sufficient for success; planners need training in business creation, operations, and marketing; differentiation is important and is achieved by specialization. Developing internet websites proved to be the most effective approach to attract new clients. These results provide information to people considering starting or maintaining a small business, providers of professional education and training, and business leaders seeking to improve recruitment and retention of financial planning employee retention. Implications for positive social change include providing information to policymakers who seek to support small businesses to mitigate small business failure rates, expand job creation, and provide sources for financial guidance for American employees.

Keywords: financial planning, entrepreneurship, strategic advantage, Porter's five forces

\section{Introduction}

The 21st century began with a series of various crises. After nearly a decade of economic downturns, the United States economy began to grow again in 2009 (International Labor Organization, 2009). Government policy makers and institutional leaders around the world have heralded the small business sector as a primary force leading economic recovery. Small businesses are integral to economic growth, and their success is important, but the number of small businesses is declining (Small Business Administration [SBA], 2014). In the United States, the small business sector represents $99.7 \%$ of all businesses and accounts for $60 \%$ of net new jobs with $75 \%$ of small businesses being self-employed individuals (SBA, 2014). While business starts each year number almost 500,000 , less than half survive 5 years or more (SBA, 2014).

The financial services industry is not immune to economic declines. The industry in the United States includes more than 16,000 companies with combined annual revenues of more than $\$ 30$ billion (First Research, 2014). Large firms dominate the industry with 50 of the largest companies accounting for half of the revenue. Trends in the number of financial planners in the United States

have followed the national economic trends. The number of professional financial planners leveled off

Please address queries to: Joanne Snider, who is now at Berkeley College. Email: joannesnider@hotmail.com 
during the financial crisis of 2008-2009 but began to rise again in 2010 (First Research, 2014). Forecasts for the financial industry are positive with predictions of annual industry growth of 8\% between 2014 and 2018 (U.S. Bureau of Labor Statistics, 2013). The important drivers for growth are (a) energy prices, (b) technology innovation, (c) commodity prices, and (d) the growing number of female clients (First Research, 2014). This level of growth will require additional financial planning professionals (First Research, 2014) and will create opportunities for the creation of independent financial planning firms. Individuals who are considering starting a business may benefit from an understanding of successful strategies used by others.

Small business owners need business strategies that differ from those of large firms, but owners often lack training in business and marketing strategies. Specifically, financial planners are trained to provide planning services that include topics such as (a) debt reduction, (b) asset accumulation, (c) college savings, (d) retirement, (e) estate planning, and (f) tax planning (see Certified Financial Planning [CFP] Board of Standards website: http://www.cfp.net). The training is rigorous and focused on technical expertise but does not include marketing techniques or business operations. Individuals who attempt to start a business without sufficient skills suffer a high risk of failure (Luca \& Cazan, 2011).

In addition to training needs, financial planners face challenges from many sources. New and complex investment products may be difficult to understand, and small business owners often find staying abreast of innovations difficult (First Research, 2014). In addition, financial advisory firms are subject to regulation by at least three regulatory bodies: the Securities and Exchange Commission, the Financial Industry Regulatory Authority, and the individual states in which they operate. Moreover, increased regulatory oversight such as the Dodd-Frank Wall Street Reform and Consumer Protection Act of 2010 adds additional levels of scrutiny and an overhead burden that small firm owners find difficult to meet (First Research, 2014).

Increased competition for financial planning firms comes from many sources. The passage of the Gramm-Leach-Bliley Act of 1999 created the opportunity for bankers to offer investment and insurance services along with commercial banking. In addition, accountants and other professionals are increasing their capacity to provide financial planning advice. Furthermore, free online tools serve the needs of some clients who favor technology over personal advising. Financial planners need to be aware of the competitive forces that affect their industry so they can develop strategies to help establish and maintain their position in the industry (Porter, 1980).

\section{Purpose}

The purpose of this qualitative case study was to explore the success factors and strategies of 12 independent financial planning small business owners who achieved profitability and had been in business for more than 5 years. The intention was to understand the success factors and strategies that helped the owners maintain their businesses despite a highly volatile economy. The owners comprised seven women and five men in the New York City, New York, area, the number of employees in their respective firms ranged from one to five, and the experience of the business owners ranged from 5 to 30 years in financial planning. Personal, in-depth interviews were recorded, and data were gathered from business brochures and advertisements. The participants verified the accuracy of their transcriptions. The results of this study contribute to business practice by providing information to individuals who are considering starting a financial planning firm and to managers who want to improve recruitment or retention of financial planners. The findings contribute to social change by assisting policy makers in formulating policies that mitigate small business failure rates, thus contributing to new job creation and national economic growth. 


\section{Conceptual Framework}

The basis for this study was entrepreneurship theory combined with Porter's model of competitive strategy. Entrepreneurship, a developing field with no unique originator, focuses on business creation and innovation (Andersen, 2012). Strategic management includes the study of how businesses grow and are maintained over time. Porter (1980), one of the pioneers in strategy, studied why some firms' owners are able to grow their organizations while others fail. Further, Porter argued that for firms to outperform others, owners needed to implement one of three strategies: (a) cost leadership, (b) differentiation, and (c) focus, or a combination of these. This study combined the two concepts, both of which contribute to an understanding of how small business owners of independent financial planning firms can achieve profitability and maintain a business for more than 5 years.

\section{Literature Review}

This section includes a brief review of studies relating to entrepreneurship and Porter's five forces model of strategic management. The discussion focuses on how the theoretical concepts apply to small business owners of financial planning firms.

\section{Entrepreneurship and Personality Traits}

In an attempt to increase the creation of new businesses with resulting increases in employment and economic development, government leaders, institutional managers, and academic administrators have attempted to find ways to encourage the development of new entrepreneurs (Arthur \& Hisrich, 2011; Caliendo, Fossen, \& Kritikos, 2014). One popular approach was developed by psychologists and involved a five-factor personality model including (a) extraversion, (b) openness to experience, (c) emotional stability, (d) agreeableness, and (e) conscientiousness (McCrae \& John, 1992).

Surprisingly, when economists attempted to apply the model, they had mixed results and found only the first three traits were good predictors of becoming an entrepreneur; conscientiousness and agreeableness were strong predictors of business failure (Caliendo et al., 2014). Other factors were found to be associated with successful entrepreneurs.

Studies show that entrepreneurs, while commonly described as fearless risk takers, are individuals who recognize risks and cautiously deal with them (Caliendo \& Kritikos, 2012). Entrepreneurial behavior includes taking initiative, creating and organizing mechanisms to achieve objectives, and accepting the risk of failure (Arthur \& Hisrich, 2011). Entrepreneurs have a need to achieve something or to create something new (Arthur \& Hisrich, 2011). They have a passion for what they do (Cardon, Gregoire, Stevens, \& Patel, 2013).

A popular belief is that business owners' primary motivation is the desire for financial rewards (Carter, 2011). Studies show, however, that almost all entrepreneurs exhibit a high degree of autonomy even though it may require a tradeoff with financial rewards (Caliendo \& Kritikos, 2012). Croson and Minniti (2012) found that self-employed individuals were willing to accept lower income in exchange for the psychical benefits anticipated. Carter (2011) found that flexibility and job satisfaction were important forms of compensation for entrepreneurs.

These studies contribute to our understanding that entrepreneurial motivations are complex. Entrepreneurs are extraverts who are open to new ideas and have the emotional stability to deal with uncertainty. They are individuals who have a need to achieve, a high degree of autonomy, and a passion for what they do. 


\section{Human Capital and Entrepreneurship}

While many people express a desire for entrepreneurship and may exhibit entrepreneurial personalities, few are successful (Arthur \& Hisrich, 2011). Luca and Cazan (2011) posited that those who fail may lack the skills to succeed or the knowledge and ability to identify markets, conduct effective marketing, and understand tax laws. They may lack sufficient human capital (Solomon, Bryant, May, and Perry, 2013).

Human capital includes (a) formal education, (b) training, (c) work experience, (d) parental background, (e) skills, and (f) knowledge (Unger, Rausch, Frese, \& Rosenbusch, 2011). Block, Hoogerheide, and Thurik (2013) determined the higher an individual's level of the education, the higher the probability that the individual will start a business. Van Praag, Witteloostuijn, and Van Der Sluis (2013) investigated the effects of formal education on income returns for entrepreneurs as opposed to employees. The researchers found there were on average between $2 \%$ and $13 \%$ higher returns for each year of formal education for entrepreneurs compared to employees (Van Praag et al., 2013).

While these studies have explored the effects of education in general, many policymakers promote entrepreneurial education, assuming that individuals can learn entrepreneurship skills regardless of personality characteristics. However, studies on the relationship between entrepreneurial education and successful entrepreneurship have yielded mixed results. Von Graevenitz, Harhoff, and Weber (2010) found that an entrepreneurship education was valuable in determining more clearly whether students were suited to entrepreneurship. While training may not increase entrepreneurial ability, it may help to minimize failure on the part of those who are uncertain about their ability.

\section{Business Survivability}

The motivating factors and characteristics that drive business startup may not be the same as those that contribute to business survivability. Many researchers have analyzed the factors contributing to small business survival with interesting results. Mayer-Haug, Read, Brinckmann, Dew, and Grichnik (2013) found that planning was more important than entrepreneurial skills. Coleman, Cotei, and Farhat (2013) found that financial capital at startup was the most important factor in business survival. Sok, O'Cass, and Sok (2013) found that the relationships among marketing, innovation, and learning capabilities created a synergy that prevented competitors from imitating the firm, thus enhancing marketing outcomes. Ayala and Manzano (2014) emphasized entrepreneurial resourcefulness as important to survivability. Solomon et al. (2013) found that cognitive skills were not sufficient for business success but that technical assistance in marketing and financial planning had a positive impact on business growth and success. Porter's approach provided an analytical model that addressed survivability from a different perspective.

\section{Porter's Model of Competitive Strategy}

Porter (1980; 2008) concluded the business environment contains five competitive forces that must be analyzed: (a) entry barriers, (b) supplier power, (c) buyer power, (d) threat of substitutes, and (e) competitive rivalry. Porter's (1980) fundamental premise was that business owners need to differentiate their businesses from others in their industry. Porter (1980) advised that firm owners could overcome competitive forces by choosing one of three broad strategies: overall cost leadership, differentiation, or focus. Cost leadership stresses efficiency and high volume, differentiation stresses innovation, focus stresses focusing on a particular market segment and may include cost leadership, differentiation, or both. Should firms fail to choose a strategy in at least one of these dimensions, they would be in a poor strategic position to achieve and maintain profitability (Porter, 1980). 
Porter's model has helped businesses in a variety of industries including manufacturing, retail, the hotel and food industries, as well as the service sector (Dobbs, 2014; Oraman, Azabagaoglu, \& Inan, 2011). Business strategists need analytical tools to determine ways to keep up with changes in an industry as a whole. Porter's model has proved to be an effective tool for business analysts in many cultures and is applicable to financial planning firms.

\section{Need for Financial Planning}

One of the serious outcomes of the financial crisis of 2008-2009 was the erosion of confidence of consumers concerning financial institutions (Hansen, 2012). However, the need for financial planning remains. The complexity of financial products can be overwhelming to consumers who have become more cost-conscious as a result of increased competition and the global slowdown (Nejad \& Estelami, 2012). The CFP Board reported that in 2012, 28\% of American households used a financial planner or adviser and more were likely to do planning in the future (Certified Financial Planner Board of Standards, 2013). In an empirical study, Marsden, Zick, and Mayer (2011) found that individuals who worked with an adviser engaged in goal setting, calculated retirement and other needs, accumulated increased emergency funds, and had increased confidence in meeting their financial goals. In another study, Hunt, Brimble, and Freudenberg (2011) found that when clients had a trusting relationship with their financial planner, the clients felt more enabled to make good financial decisions. When individuals actively engage in setting goals and identifying strategies, their lives are enhanced (Irving, 2012). Successful financial planning firms are those that forge strong relationships with their clients. Projections (U.S. Bureau of Labor Statistics, 2013) show the need for financial planners will increase in the coming years. Those who prepare well for the future may reap the benefits of forming their own firms. The results of this study may provide detailed information from others who have survived in spite of turbulent economic times. It may also provide managers with information they can use to understand who to motivate and retain their employees.

\section{Methodology}

The primary research question that guided this study was, "What are the success factors and strategies of independent financial planning small business owners who have achieved profitability and have been in business for more than 5 years?" Personal, semistructured interviews with 12 small business owners of financial planning firms were conducted, and client newsletters and organization websites were examined. The participants included seven women and five men. All businesses existed for more than 5 years and the number of employees ranged from one to five. The firms met the criteria for defining a small business according to the SBA; that is, firm revenues were less than $\$ 35.5$ million, and the number of employees was less than 50 .

A literature review of peer-reviewed studies yielded a basis for theoretical propositions relating to the primary research question. Following an approach described by Yin (2014) who encouraged the use of guided conversations, a list of open ended questions was used for the interviews. When the interviews were complete, the responses were coded to protect privacy (participant names were coded as P1, P2, .., P12), and NVivo10 (QSR International) software was used to assist in identifying recurring words and phrases, and, ultimately, common themes. Table 1 contains the questions, theoretical propositions, and recurring themes. 
Table 1: Interview Questions, Theoretical Proposition, and Coded Themes

\begin{tabular}{|c|c|c|c|}
\hline Number & Participant question & Theoretical proposition & Rationale/Coded theme \\
\hline 1. & $\begin{array}{l}\text { Please describe when and } \\
\text { how you decided to start } \\
\text { your own business. }\end{array}$ & $\begin{array}{l}\text { Entrepreneurial } \\
\text { characteristics and } \\
\text { motivation }\end{array}$ & $\begin{array}{l}\text { Desire for independence, desire } \\
\text { to help people, love financial } \\
\text { planning }\end{array}$ \\
\hline 2. & $\begin{array}{l}\text { Please describe your } \\
\text { education, training, and } \\
\text { skills that enabled you to } \\
\text { maintain profitability. }\end{array}$ & $\begin{array}{l}\text { Specific business skills } \\
\text { needed or acquired }\end{array}$ & $\begin{array}{l}\text { CFP Training, work experience, } \\
\text { personal communication skills }\end{array}$ \\
\hline 3. & $\begin{array}{l}\text { How do you differentiate } \\
\text { your firm from your } \\
\text { competitors? }\end{array}$ & $\begin{array}{l}\text { Business differentiation } \\
\text { characteristics }\end{array}$ & $\begin{array}{l}\text { Fee structure, guidance only, } \\
\text { customized service }\end{array}$ \\
\hline 5. & $\begin{array}{l}\text { How do you perceive the } \\
\text { value of social media or the } \\
\text { use of a company website? }\end{array}$ & Use of social media & Website is essential \\
\hline 6. & $\begin{array}{l}\text { What advice would you give } \\
\text { another financial planner } \\
\text { who was considering } \\
\text { embarking on opening a } \\
\text { small business? What skills } \\
\text { or specific training would } \\
\text { you recommend? }\end{array}$ & Advice to others & $\begin{array}{l}\text { Credentials are crucial, } \\
\text { business/marketing plan, } \\
\text { experience, personal } \\
\text { characteristics, cash reserve }\end{array}$ \\
\hline 7. & $\begin{array}{l}\text { What else, if anything, } \\
\text { would you like to add to our } \\
\text { conversation about the } \\
\text { success factors and } \\
\text { strategies related to your } \\
\text { business' survival during } \\
\text { the first } 5 \text { years? }\end{array}$ & Other insights & $\begin{array}{l}\text { Take care of clients/add value, } \\
\text { have a game plan, be flexible, be } \\
\text { true to self, have heart }\end{array}$ \\
\hline
\end{tabular}

\section{Theme 1: Motivation for Starting a Business}

A common popular belief is that individuals start businesses because of a desire for financial rewards (Carter, 2011), but the majority (75\%) of the participants in this study stated that they started their business primarily because they wanted to be independent. This finding aligns with studies by Carter (2011) and Caliendo and Kritikos (2012) who found that self-employed individuals sought psychic rewards and were even willing to trade autonomy for financial rewards. P4 explained, "Part of it is a matter of need. I view myself unemployable. I've been a partner in several ... firms and I really love and thrive on doing my own thing." P5 stated, "It was an easy decision in the sense that there was not a single firm that I could find that I would want to work for because I'm very particular in how I think a financial planning firm should be run . . . I couldn't find all those things."

\section{Theme 2: Education, Training, and Skills Needed or Acquired}

The participants in this study emphasized the need for technical training, marketing, and communication skills. All 12 of the interviewees stated that they obtained CFP certification prior to 
starting their business. In addition to obtaining CFP certification, all participants had undergraduate degrees, and four had advanced degrees. The participants were unanimous in the belief that credentials and training were prerequisites for success. This finding aligned with studies showing there is a strong positive relationship between human capital and business success (Block et al., 2013; Unger et al., 2011).

Few of the participants had initial training in business operations and marketing. All 12 participants acquired this knowledge by working in the financial services field prior to starting a business. The business owners found that work experience helped to fill the gap in their training. As P3 stated, "The only thing they do not teach you in financial planning is marketing." This finding aligns with those of Aldrich and Yang (2013) who concluded that working as an employee could provide individuals with specific habits and routines that could prove valuable, and previous experience was an important factor in entrepreneurial success.

Only one participant had developed a strategic plan prior to starting the business, and three participants stated they had developed a one-page, cash flow summary. The remaining interviewees relied on prior work experience and strong communication skills, developing their business skills by self-study, or, as P3 stated, "I evolved by trial and error."

Three participants stressed the need for a cash reserve large enough to cover the first few years. All participants mentioned the need for resilience and perseverance, especially in the beginning when revenues are likely to be small. These findings support those of Ayala and Manzano (2014), who found that entrepreneurial resourcefulness was critical for survival.

\section{Theme 3: Differentiation as a Key to Business Survival}

A business owner may start out with a high level of skills and favorable conditions, but skills alone may not be enough to ensure success (Porter, 1991). Porter (1980) advised that firms' owners could overcome competitive forces by the use of three broad strategies: (a) cost leadership, (b) differentiation, and (c) focus, or a combination of these. The business owners in this study used all three of these strategies to some degree.

To distinguish themselves from other professionals, all participants in this study emphasized client service. All business owners stated their uniqueness lay in their high level of service or the way they delivered their services to clients. The interviewees stressed having close client relationships. They tailored fees to client situations and provided fee estimates before beginning a client engagement, ensuring that clients perceived value.

Another area that business owners used to differentiate themselves from their competitors was by focusing on a specific area of expertise, group, or type of client. For example, one participant specialized in providing advice about healthcare needs in retirement, another focused on individuals in the construction industry, while yet another worked with individuals who were in a state of transition. One participant worked with individuals who had a minimum of $\$ 3.5$ million in investable assets, while another focused on helping young professionals. One participant stated that she used her female gender as a differentiating factor, "Some people, some parts of the public, see that as equating to more trustworthiness and more conscientiousness and being more communicable." 


\section{Theme 4: Strategies Used to Maintain the Business}

Relationship management in the financial services industry is a fundamental component in company survival (Hunt et al., 2011). All business owners in this study mentioned unique customer service and consistently delivering what they promised (Miles, 2013). The owners created customer loyalty with resulting high client retention rates.

Half of the business owners in this study mentioned referrals as their primary source for new business. Referrals came from existing clients and from organizational websites. Building strong, trusting relationships with clients was important and resulted in high client satisfaction and retention. These findings are in alignment with results found by Hunt et al. (2011), whose studies reflected the important role that relationship building plays in a financial planning engagement. These findings also align with Porter's recommendation that business owners must provide a unique value proposition for their businesses to survive.

\section{Theme 5: Social Media}

Eleven of the 12 participants had company websites, and one had a website planned. All participants viewed websites as necessary for business. As P11 expressed, "I think that anyone today who holds himself out as an advisor or a business person is expected to have a company website at a minimum." P9 stated, "My website is rather simple ... it just explains a little bit more about me and my philosophy. . . If you go to my website, you'll get who I am." Three of the business owners reported using social media sites, such as LinkedIn or Facebook. This strategy is in alignment with Porter's (1980) recommendation that successful business owners need to differentiate themselves from their competitors.

\section{Theme 6: Advice to Others}

An important question for the participants was to reflect upon their own experiences and provide advice to an individual who might be considering starting a financial planning firm. The participants were generous in the advice they offered. They unanimously recommended obtaining training and credentials, specifically CFP. They also acknowledged that technical expertise was not sufficient for establishing a successful business; training in business startup and development with emphasis on marketing was equally important. Eight of the participants (67\%) recommended internships with other firms, specifically to learn best business practices and to gain experience. Three of the participants acknowledged that there were no guarantees and warned newcomers not to expect success to come quickly. P5 cautioned, "You need to give yourself some time to build your business." P9 added, "The first piece of advice would be to make sure that they have a healthy cash reserve going . . . because I don't think there's any guarantee they will succeed." P10 provided this advice, "... be prepared for hills and valleys. They have to have some money in the bank."

The business owners also cited various personality characteristics, habits, and attitudes as important keys to success. P1 advised, "The advice I would give people is to specialize in something that you're interested in. P7 advised, "Communicate a lot." P6 added, "Make sure you take care of your client." P5 stressed "adding value to clients' lives," and P10 emphasized "flexibility."

Financial planning businesses are centered on satisfying clients' needs. P11 summed it up by saying,

I think your relationships are going to be key because this is a business about people. We are not selling shoes. You can hate the salesman, but if you love 
the shoes, you are going to take the shoes anyway. There are no shoes here.

It's all relationships and contacts.

P8 succinctly added, "You gotta have heart."

\section{Summary of Findings}

In summary, several themes permeated the coded responses. Three fourths of the participants stated a desire for independence was their primary motivation for starting a business. All participants believed professional credentials to be essential for success. Surprisingly, not all participants developed a business plan prior to business startup, but many expressed the need for a marketing plan for business expansion. Strategies for differentiation included customized services, fee structures and market focus; maintaining the business depended largely on relationship skills and referrals. All of the participants regarded having a website as important, but few used social media sites such as LinkedIn and Facebook. Although several of the participants mentioned the need for a cash reserve, none of the participants mentioned financial rewards as a primary driver for business startup or as a measure of success. All participants expressed a passion for their work and found satisfaction in helping clients. Table 2 contains a summary of the findings.

Table 2: Summary of findings

\begin{tabular}{lcc}
\hline Thematic categories & $\begin{array}{c}\text { Number of } \\
\text { participants to offer } \\
\text { this perception }\end{array}$ & $\begin{array}{c}\text { Percent (\%) of } \\
\text { participants to offer this } \\
\text { perception }\end{array}$ \\
\hline Professional certification required & 12 & $100 \%$ \\
Related work experience recommended & 12 & $100 \%$ \\
Resilience/Perseverance required & 12 & $100 \%$ \\
Differentiation through fee structure/services & 12 & $100 \%$ \\
Website usage & 12 & $100 \%$ \\
Market niche & 8 & $67 \%$ \\
Marketing skills necessary & 8 & $67 \%$ \\
Strong communication skills needed & 7 & $58 \%$ \\
Growth through referrals & 6 & $50 \%$ \\
Financial gain is most important & 0 & $0 \%$ \\
\hline
\end{tabular}

\section{Conclusions and Applications to Professional Practice}

The findings of this study indicated financial planning professionals have a strong need for business and marketing knowledge prior to embarking on starting a business. Traditional training in the financial planning field includes technical training in specialized areas, but additional preparation is necessary for a financial planner to succeed. The participants in this study strongly recommended that individuals enter the profession by working in a financial planning firm. The interviewees understood the need for financial planners to become fully knowledgeable in business operations prior to branching out on their own. Professional organizations may also help satisfy this need by facilitating the establishment of apprenticeship programs in existing firms. Academic institutions may assist by facilitating internships and by including appropriate course offerings in their curricula.

The findings of this study corroborated Porter's (1980) position that to be successful, firm owners need to have a clear understanding of their strengths and place in the industry. Business owners 
need to combat competition by developing strategies that use (a) a low-cost strategy, (b) differentiation, and (c) focus, or a combination of these. To survive, firms need to provide a unique value proposition (Porter, 1980). The business owners in this study provided individual, customized guidance for clients, offered expertise in specialized areas, and had unique fee structures.

Specialization should be encouraged among financial planning professionals. Providing unique expertise within a generalized framework of comprehensive financial planning can attract clients with particular needs and can allow planners to focus efforts in an area that may eclipse competitors.

Corporate managers who employ financial planners may benefit from a strategy of specialization as well. Managers may form teams of specialists within their organization, thus providing clients with a wide variety of expertise from a single source. In addition to increasing client satisfaction, Frey, Bayon, and Totzck (2013) found that increased client satisfaction has a corresponding increase in employee satisfaction, resulting in lower employee turnover.

Individuals desiring to be successful as independent financial planners must be client-centered as well as business-oriented. The ability to attract clients requires good communication skills and relationship management, both of which are the hallmarks of sustainability (Luca \& Cazan, 2011; Solomon et al., 2013). How to find clients, how to make presentations, and how to market oneself are skills that are prerequisites for business success (Mayer-Haug et al., 2013). However, these skills are often overlooked in favor of technical training. The ability to use networking effectively may provide a strong basis for filling gaps in marketing, but individuals may need assistance in learning how to network (Jones \& Rowley, 2011). Professional organizations should offer training in these skills to benefit their members and increase their membership.

Financial planners benefit individuals and households in many ways. Planners provide professional guidance in (a) budgeting, (b) investing, (c) managing risk, (d) reducing tax liabilities, and (e) estate planning. Financial planners who establish their own businesses help individual clients, and are a source of new job creation. Strong financial foundations mitigate unemployment and economic uncertainty for both planners and their clients. Assisting small business owners of financial planning firms encourages economic growth and business expansion. More individuals can achieve financial independence to become their own source of financial security.

\section{References}

Aldrich, H. E., \& Yang, T. (2013). How do entrepreneurs know what to do? Learning and organizing in new ventures. Journal of Evolutionary Economics, 24, 59-82. doi:10.1007/s00191-0130320-x

Andersen, E. S. (2012). Schumpeter's core works revisited. Journal of Evolutionary Economics, 22, 627-648. doi:10.1007/s00191-012-0281-5

Arthur, S. J., \& Hisrich, R. D. (2011). Entrepreneurship through the ages: Lessons learned. Journal of Enterprising Culture, 19, 1-40. doi:10.1142/S0218495811000696

Ayala, J. C., \& Manzano, G. (2014). The resilience of the entrepreneur. Influence on the success of the business. A longitudinal analysis. Journal of Economic Psychology, 42, 126-135. doi:10.1016/j.joep.2014.02.004

Block, J. H., Hoogerheide, L., \& Thurik, R. (2013). Education and entrepreneurial choice: An instrumental variables analysis. International Small Business Journal, 31, 23-33. doi:10.1177/0266242611400470 
Caliendo, M., Fossen, F., \& Kritikos, A. (2014). Personality characteristics and the decision to become and stay self-employed. Small Business Economics, 42, 787-814. Retrieved from http://link.springer.com/journal/11187

Caliendo, M., \& Kritikos, A. (2012). Searching for the entrepreneurial personality: New evidence and avenues for further research. Journal of Economic Psychology, 33, 319-324. doi:10.1016/j,joep.2011.06.001

Cardon, M. S., Gregoire, D. A., Stevens, C. E., \& Patel, P. C. (2013). Measuring entrepreneurial passion: Conceptual foundation and scale validation. Journal of Business Venturing, 28, 373396. doi:10.1016/jbusvent.2012.03.003

Carter, S. (2011). The rewards of entrepreneurship: Exploring the incomes, wealth, and economic well-being of entrepreneurial households. Entrepreneurship Theory and Practice, 35, 39-55. doi:10.1111/j.1540-6520.2010.00422.x

Certified Planner Board of Standards. (2013). Financial planning profiles of American households: The 2013 household financial planning survey and index. Retrieved from https://www.cfp.net/docs/public-policy/2013-fin-planning-profiles-of-amer-households.pdf

Coleman, S., Cotei, C., \& Farhat, J. (2013). A resource-based view of new firm survival: New perspectives on the role of industry and exit route. Journal of Developmental Entrepreneurship, 18, 1-25. doi:10.1142/S1084946713500027

Croson, D. C., \& Minniti, M. (2012). Slipping the surly bonds: The value of autonomy in selfemployment. Journal of Economic Psychology, 33, 355-365. doi:10.1016/j.joep.2011.05.001

Dobbs, M. E. (2014). Guidelines for applying Porter's five forces framework: A set of industry analysis templates. Competitiveness Review, 24, 32-45. doi:10.1108/CR-06-2013-0059

Dodd-Frank Wall Street Reform and Consumer Protection Act of 2010, H.R. 4173, 111th Cong. (2010).

First Research. (2014, February 17). Industry profile: Financial planners and investment advisers. Retrieved from http://www.firstresearch.com/Industry-Research/Financial-Planners-andInvestment-Advisers.html

Frey, R. V., Bayon, T., \& Totzek, D. (2013). How customer satisfaction affects employee satisfaction and retention in a professional services context. Journal of Service Research, 16, 503-517. doi:10.1177/1094670513490236

Gramm-Leach-Bliley Act of 1999, Pub. L. No. 106-102, § 113, Stat. 1338 (1999).

Hansen, T. (2012). Understanding trust in financial services: The influence of financial healthiness, knowledge, and satisfaction. Journal of Service Research, 15, 280-295. doi:10.1177/1094670512439105

Hunt, K., Brimble, M., \& Freudenberg, B. (2011). Determinants of client-professional relationship quality in the financial planning setting. Australasian Accounting Business and Finance, 5, 69-99. Retrieved from http://ro.uow.edu.au/aabfj/

http://ro.uow.edu.au/cgi/viewcontent.cgi?article=1169\&context=aabfj

International Labor Organization. (2009). Impact of the financial crisis on finance sector workers. Retrieved from http://www.ilo.org/wcmsp5/groups/public/@dgreports/@dcomm/documents/meetingdocument/ wcms_103263.pdf 
Irving, K. (2012). The financial life well-lived: Psychological benefits of financial planning. Australasian Accounting Business and Finance, 6, 47-59. Retrieved from http://ro.uow.edu.au/aabfj/vol6/iss4/4/

Jones, R., \& Rowley, J. (2011). Entrepreneurial marketing in small businesses: A conceptual exploration. International Small Business Journal, 29, 25-36. doi:10.1177/0266242610369743

Luca, M. R., \& Cazan, A.M. N. (2011). Involvement in entrepreneurial training and personality. Procedia Social and Behavioral Sciences, 30, 1251-1256. Retrieved from http://www.sciencedirect.com/science/article/pii/S1877042811020672

Marsden, M., Zick, C. D., \& Mayer, R. N. (2011). The value of seeking financial advice. Journal of Family and Economic Issues, 32, 625-643. doi:10.1007/s10834-011-9258-z

Mayer-Haug, I., Read, S., Brinckmann, J., Dew, N., \& Grichnik, D. (2013). Entrepreneurial talent and venture performance: A meta-analytic investigation of SMEs. Research Policy, 42, 12511273. doi:10.1016/j/respol.2013.03.001

McCrae, R. R., \& John, O. P. (1992). An introduction to the five-factor model and its applications. Journal of Personality, 60, 175-215. Retrieved from http://onlinelibrary.wiley.com/doi/10.1111/jopy.1992.60.issue-2/issuetoc

Miles, P. C. (2013). Competitive strategy: The link between service characteristics and customer satisfaction. International Journal of Quality and Service Sciences, 5, 395-414. doi:10.1108/IJQSS-03-2013-0007

Nejad, M. G., \& Estelami, H. (2012). Pricing financial services innovations. Journal of Financial Services Marketing, 12, 120-134. Retrieved from http://www.palgrave-journals.com/fsm/

Oraman, Y., Azabagaoglu, M. O., \& Inan, I. H. (2011). The firms' survival and competition through global expansion: A case study from food industry in FMCG sector. Procedia Social and Behavioral Sciences, 24, 188-197. doi:10.1016/j.sbspro.2011.09.021

Porter, M. E. (1980). Competitive strategy. New York, NY: Free Press.

Porter, M. E. (1991). Towards a dynamic theory of strategy. Strategic Management Journal, 12, 95117. Retrieved from http://smj.strategicmanagement.net/

Porter, M. E. (2008). The five competitive forces that shape strategy. Harvard Business Review, 86(1), 25-40. Retrieved from https://hbr.org/2008/01/the-five-competitive-forces-that-shapestrategy

Small Business Administration (SBA). (2014). Office of Advocacy: Frequently asked questions. Retrieved from https://www.sba.gov/sites/default/files/advocacy/SB-FAQ-2017-WEB.pdf

Sok, P., O'Cass, A., \& Sok, K. M. (2013). Achieving superior SME performance: Overarching role of marketing, innovation, and learning capabilities. Australasian Marketing Journal, 21, 161167. doi:10.1016/j.ausmj.2013.04.001

Solomon, G. T., Bryant, A., May, K., \& Perry, V. (2013). Survival of the fittest: Technical assistance, survival and growth of small businesses and implications for public policy. Technovation, 33, 292-301. doi:10.1016/j.technovation.2013.06.002

Unger, J. M., Rauch, A., Frese, M., \& Rosenbusch, N. (2011). Human capital and entrepreneurial success: A meta-analytical review. Journal of Business Venturing, 26, 341-358. doi:10.1016/j.jbusvent.2009.09.004 
U.S. Bureau of Labor Statistics. (2013). Occupational employment statistics. Retrieved from http://www.bls.gov/oes/current/oes132052.htm

Van Praag, M., Van Witteloostuijn, A., \& Van Der Sluis, J. (2013). The higher returns to formal education for entrepreneurs versus employees. Small Business Economics, 10, 375-396. doi:10.1007/s11187-012-9443-y

Von Graevenitz, G., Harhoff, D., \& Weber, R. (2010). The effects of entrepreneurship education. Journal of Economic Behavior \& Organization, 76, 90-112. doi:10.1016/j.jebo.2010.02.015

Yin, R. K. (2014). Case study research (5th ed.). Thousand Oaks, CA: Sage.

The International Journal of Applied Management and Technology (IJAMT), sponsored by Walden University's School of Management, is a peer-reviewed, online journal that addresses contemporary national and international issues related to management and technology. The objectives of the IJAMT are to: (a) encourage collaborative and multi-disciplinary examinations of important issues in business and technology management, and (B) engage scholars and scholar-practitioners in a dynamic and important dialogue.

Walden University Publishing: http://www.publishing.waldenu.edu 